\title{
THE EFFECTIVENESS OF FISHBONE METHOD ON STUDENTS' WRITING ABILITY OF ARGUMENTATIVE TEXT
}

\author{
Meli Fauziah' \\ ${ }^{1}$ Institut Agama Islam Negeri Curup
}

\begin{tabular}{l}
\hline \hline Info Artikel : \\
\hline Diterima 12 Desember 2021 \\
Direvisi 27 Januari 2022 \\
Dipublikasikan 30 Januari 2022
\end{tabular}

\section{Kata Kunci: (9 pt) \\ Diangram Tulang ikan \\ Teks argumentative \\ Kemampuan Menulis}

\begin{abstract}
ABSTRAK
Penelitian ini berangkat dari beberapa permasalahan yang dihadapi siswa SMA dalam menulis teks argumentatif seperti kesulitan dalam mengorganisasikan ide, kurangnya niat dalam menulis, dan kurangnya teknik khususnya dalam menulis teks argumentatif. Tujuan dari penelitian ini adalah untuk mengetahui apakah penggunaan diagram tulang ikan dapat meningkatkan kemampuan siswa dalam menulis teks argumentasi atau tidak. Penelitian ini merupakan penelitian tindakan kelas. Subjek penelitian ini berjumlah 34 siswa yang terdiri dari 12 laki-laki dan 22 perempuan. Instrumen penelitian ini adalah tes menulis, daftar periksa observasi siswa dan guru, dan wawancara. Penelitian ini dilakukan dalam dua siklus yang meliputi perencanaan, tindakan, observasi, dan refleksi. Hasil penelitian ini menunjukkan bahwa terdapat peningkatan kemampuan siswa dalam menulis teks argumentasi pada setiap siklusnya. Pada pre-test, nilai rata-rata siswa adalah 58,2. Pada siklus 1, nilai rata-rata siswa adalah 66,7. Pada siklus 2 nilai rata-rata siswa adalah 77,7 . Dapat diungkapkan bahwa diagram tulang ikan efektif dalam meningkatkan kemampuan siswa dalam menulis teks argumentasi.
\end{abstract}

\begin{abstract}
This research departed from some problems faced by senior high school students in writing argumentative text such as their difficulties to organize the idea, lack of intention in writing, and lack of technique especially in writing argumentative text. The objective of this research was to find out whether the use of fishbone diagram could improve students' ability in writing argumentative text or not. This research was a classroom action research. The subject of this research was 34 students consisted of 12 males and 22 females. The instruments of this research were writing test, students' and teacher's observation checklist, and interview. The research was conducted in two cycles which included plan, action, observation, and reflection. The result of this research showed that there was an improvement of students' ability in writing argumentative text in every cycle. In the pre-test, the students' mean score was 58.2. In cycle 1, the students' mean score was 66.7. In the cycle 2, the mean score of the students was 77.7. It could be revealed that fishbone diagram was effective in improving students' ability in writing argumentative text.
\end{abstract}

\section{Abstrak dan kata kunci ditulis dengan menggunakan bahasa Indonesia dan Bahasa Inggris.}

This is an open access article distributed under the Creative Commons Attribution License, which permits unrestricted use, distribution, and reproduction in any medium, provided the original work is properly cited. (C2019 by author.

Koresponden: (9 pt)

Meli Fauziah

Email: melifauziah@iaincurup.ac.id

\section{INTRODUCTION}

English plays an important role in determining the final score or the graduation of senior high school students. In learning English, there are two kinds of skill that should be mastered by the students, namely; productive and receptive skill. Productive skill is divided into two basic skills are speaking and writing. Meanwhile, reading and listening are included to receptive skill. By mastering those four basic skills, the students will be able to produce a good spoken or written discourse. 
As an enjoyable activity, the writers can deliver their thought fully through writing. According to Byrne, writing is the production of graphic symbols to form words in a sequence of sentence arranged in a particular order and linked together in certain ways, also writing is the process of encoding a message to transfer meaning to the reader. In addition, Brown also said that writing products are often the result of thinking, drafting, and revising procedures that require specialized skills, which is not every speaker can develop naturally. Therefore, it can be concluded that writing is one of the important ways to communicate people's thoughts and to share their ideas. They can write freely in order to express their feeling.

In writing skill, Senior High School Students are intended to master some genres of text. One of the genre is argumentative text. Argumentative text is a kind of text which refers to the writer's opinion about surrounding phenomenon. The purpose of this text is to persuade and conceive the readers with the writer's stance. Actually, there are some problems faced by senior high school students dealing with writing argumentative text such as the difficulties in organizing idea, lack of intention in writing, and lack of technique in writing argumentative text. It was actually caused by some factors. First, the English teacher still used manual technique that could not catch the students' attention. The teachers just gave explanation and exercises during the learning process so it made the students lost their interest in writing as well as the teaching and learning process seemed monotonous. Second, the students were given limited time to write their argumentative text. So, they could not expand their ideas widely and freely. Actually, when they were asked to write an argumentative text, they knew what they wanted to write, but they did not know how to organize their ideas. Therefore, the researcher tried to solve this problem by applying fishbone diagram in order to make them easier to write argumentative text.

Fishbone diagram known as cause and effect diagram found by Kaoru Ishikawa is one of the best technique in teaching writing argumentative text. A fishbone diagram consists of three parts. First, the head, it is as a problem or topic which will be analyzed. Second, the body, it is as a description of a problem or topic. The last, the tail, it is as a result of the problem. Moreover, this technique can help the students to determine the cause and effect of one problem statement by using a model like a skeleton of a fish. It can be very enjoyable for students to be creative in writing.

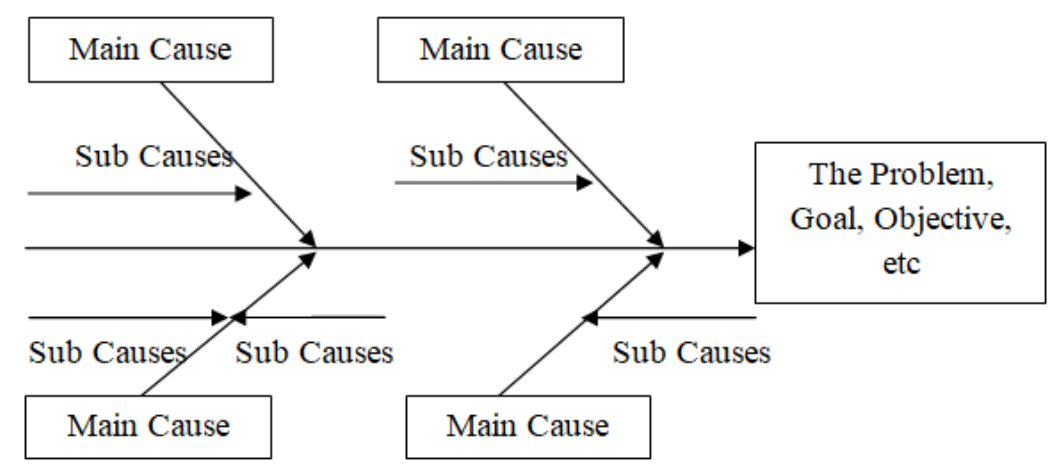

Figure 1. Fishbone Diagram

Fishbone diagram had been applied by some researchers. First, it was applied by Subaedah in her research entitled "Improving the Students' Writing Skills through Fishbone Method (a classroom action research in class XI sepeda motor of SMK Muhammadiyah 2 Bontoala, Makassar). Two cycles had been conducted in her research, and the result, fishbone method could increase the students' skill in writing descriptive text.

Second, it was applied by Shan Li in her research entitled "Improving the Quality of Proposal for Science and Technology Program Using Fishbone Analysis." It also used two cycles and the result was fishbone analysis could improve the quality of proposal for science and technology program.

Third, it was applied by Basuki Rahmat in his research entitled "Improving Students' Vocabulary Mastery by Using Fishbone Strategy." He used a quasi-experimental research which used two classes are experiment and control. At the end of his research, he found that students' vocabulary mastery in experimental class is higher than control class. The mean score of experimental group was 62,80 and the mean score of control group was 52,00. It proved that fishbone strategy could increase students' vocabulary mastery.

Thus, it is clear that fishbone diagram can significantly improve students' English ability especially in writing skill and vocabulary mastery. Moreover, fishbone diagram can also be used to improve the quality of proposal for science and technology program. 


\section{METHODOLOGY}

The research applied classroom action research which would focus on a particular group of students in a certain classroom. Mills defined action research as any systematic inquiry conducted by teacher researcher, principals, and school counselors in the teaching and learning environment to gather information about (a) how their particular school operates, (b) how teachers teach, and (c) how well their students learn.

The subject of this research was 34 senior high school students with 12 males and 22 females. Some instruments such as writing test, observation checklist, and interview were used to gather the data. It was done following four fundamental steps in action research such as planning, action, observing, and reflecting.

After the data gathered, the researcher assessed the students' result using the writing criteria scale proposed by Heaton (2004) which include content, organization, vocabulary, language use, and mechanics. Besides, to support the data analysis, the researcher used the formula adopted from Sudijono as followed:

$$
\begin{array}{ll}
\text { Notes: } \\
P=(f: n) \times 100 \% & \mathrm{P}=\text { Percentage number of students who pass the standard score } \\
& \mathrm{f}=\text { Number of students who pass the standard score } \\
& \mathrm{n}=\text { Total number of the students }
\end{array}
$$

In order to measure the successful of this research, the researcher applied two indicators; first, at least $70 \%$ of students reach the score $\geq 73$ and at least $70 \%$ of students are active and motivated in the classroom.

\section{FINDING AND DISCUSSION}

The result of this research showed a significant improvement towards students' writing ability in argumentative text. It can be shown from improvement of students' mean score in pre-test, cycle 1 and cycle 2 was significant. It could be seen clearly from the chart below:

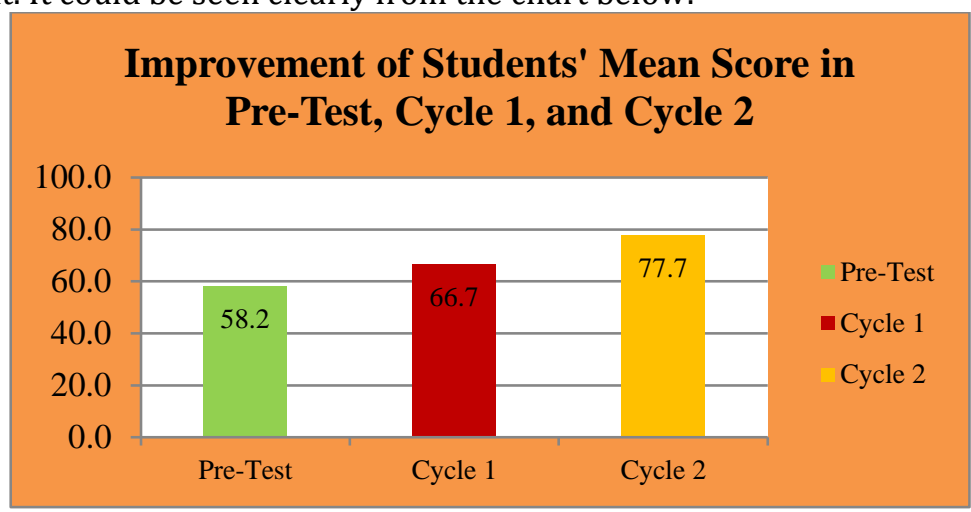

Chart 1: Improvement of Students' Mean Score for Each Cycle

The students' mean score in pre-test is 58.18 increased into 66.67 in cycle 1 and significantly increased into 77.74 in cycle 2 . The mean score in the last cycle proved that more than $70 \%$ of students have reached minimum standard score. Based on the result of each cycle, fishbone diagram affected improvement on students' writing ability in argumentative text. Basically, there were also improvements for each aspect of writing as displayed on the chart below: 


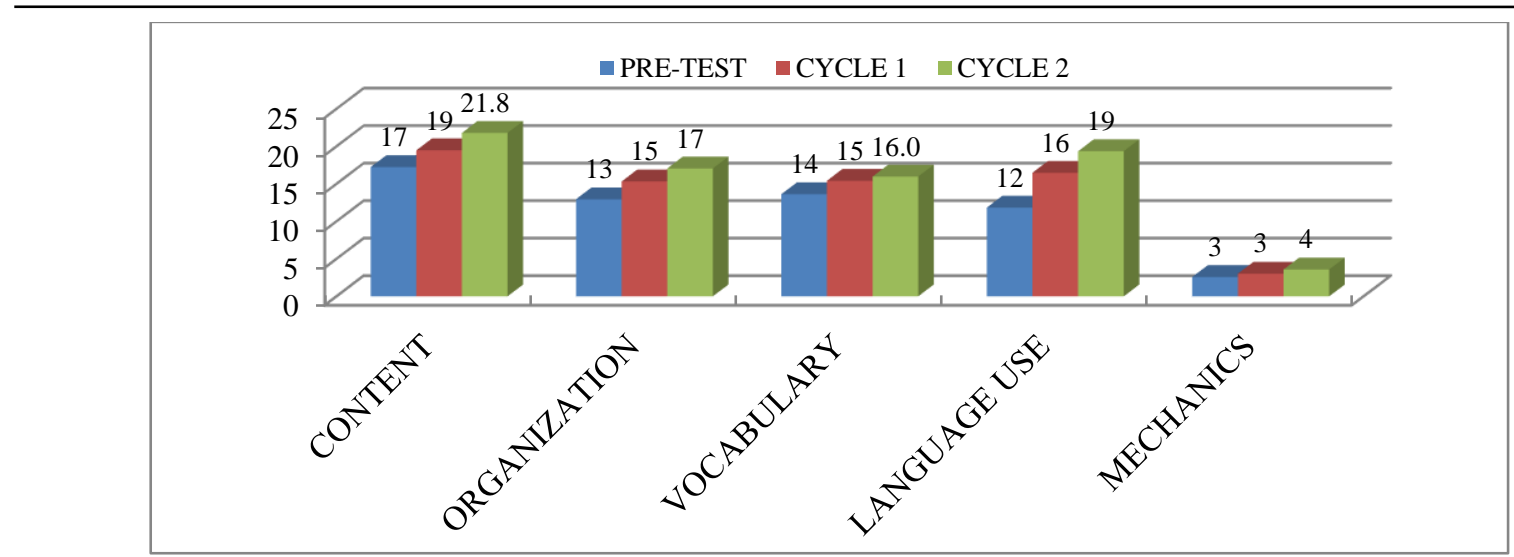

Chart 2: The Improvement of Students' Mean Score Per-Aspects of Scoring in Each Cycle

As can be seen from the chart above, the improvement happened for each aspect of writing score. The students gradually were able to write argumentative text. This result was also similar to the result of some previous studies. First, the research conducted by Subaedah was similar to the result of this research which also proved that the students' writing ability could be achieved and improved by using fishbone method. Then, by using fishbone method, the students finally realized that writing is not difficult. They can arrange the idea systematically for each paragraph. Therefore, it can be concluded that fishbone method can improve students' writing ability in argumentative text.

Second, the result of this research was also in line with the research conducted by Shan Li , which also proved that fishbone diagram could improve the quality of proposal for science and technology program. Furthermore, using fishbone method could also improve students' vocabulary mastery. As similar as research done by Basuki Rahmat which conducted an experimental research, proved that the result in experimental class by using fishbone method was higher than control class. Moreover, using fishbone method could also give beneficial impact to the English teacher to make various class activities in order to prevent students' boredom. This result was similar to the theory by Varsha, et al that fishbone method could not only increase the students' ability in writing argumentative text, but it also could encourage group participation and trained the students' to work in team. Finally, from the discussion above, the researcher conclude that using fishbone method was effective to improve students' writing ability in argumentative text. It also facilitated the students to be creative and being motivated in teaching and learning process.

\section{CONCLUSION}

Based on the research findings and discussion that had been explained above, the researcher concluded that the usage of fishbone diagram was effective to improve the students' ability in writing argumentative text. It also could decrease students' problems in writing argumentative text such as lack of intention in writing and difficulties in organizing the idea. On the other hand, teaching English writing by using this technique could also make students motivated, active, and creative in their learning process. Therefore, it was appropriate to be applied in teaching writing argumentative text for senior high school students.

\section{REFERENCES}

Basuki, R. (2019). Improving Students' Vocabulary Mastery by Using Fishbone Strategy.IAINBengkulu.Unpublished

Brown, D. (2007). Teaching by Prociples: An Interactive Approach to Language Pedagogy. USA: Pearson Longman

Byrne, D. (2017). Teaching Writing Skills. USA: Longman

Haycraft, J. (2016). An Introduction to English Language Teaching. United States: Longman

Heaton, JB. (2004). Writing English Language Test. London and New York: Longman

Mills, G.E. (2011). Action research: A guide for the teacher researcher (4th ed.). Boston: Pearson

Shan, Li. (2019). Improving the Quality of Proposal for Science and Technology Program Using Fishbone Analysis. Taiwan: S\&T Policy Research and Information Center.

Subaedah. (2015). Improving students' writing skills through fishbone method (a classroom action research in class XI sepeda motor of SMK Muhammadiyah 2 Bontoala Makassar.

Sudijono, Anas. (2008). Pengantar Statistik Pendidikan. Jakarta: RajaGrafindo Persada.

Varsha, et al. (2015). A Review on : Fishbone Diagram. India: World Journal of Pharmaceutical Research (WJPR). 